\title{
Impacts of Visual Merchandising on Customer Buying Behavior in Bangladeshi Clothing Stores
}

\author{
Hitoishi Khisa, Md. Enamul Hoque, Md. Faisal Hanif, Mehedi Hasan Chaion, Mahbubur Rahman, \\ Md. Jamir Uddin, Sumaiya Siddika, Tarikul Islam
}

\begin{abstract}
Apparel stores always have to develop their system to survive in the market. Attracting new customers and satisfying the running customers are the necessity for continuing the business. In this regard, retailers design new techniques and gradually reshape it for adopting a competitive market. Visual merchandising is one of the philosophies where retailers are not only presenting their products but also attracting new customers outside the windows. There are a lot of elements in visual merchandising, but its significance varies from region to region. In this study, we considered the local apparel stores for finding the visual merchandising elements and also analyzing which elements are satisfied more for buying a new product in Chittagong. The result of the study showed what are the noteworthy key attributes of visual merchandising affecting consumers buying behavior in that region.
\end{abstract}

Index Terms - Apparels, Buying behavior, Consumer, Retails, Stores, Visual Merchandising.

\section{INTRODUCTION}

In 2020, the GDP growth rate of Bangladesh is $8 \%$, which is higher compared to other neighboring countries, including India [1]. The rapid growth of the economy has created new opportunities for retail business for both local and foreign fashion brands in the Bangladeshi market [2]. Indeed, apparel stores are facing more competition for globalization. Nevertheless, high service quality ensures high customer satisfaction attaining the differentiation with other clothing stores [3]. Over the years, apparel stores have reformed their

Published on November 30, 2020.

Hitoishi Khisa, Department of Textile Engineering, Port City International University, Bangladesh.

(e-mail: hitoishi123@gmail.com)

Md. Enamul Hoque, Department of Apparel Engineering, Bangladesh University of Textiles, Bangladesh.

(e-mail: enamul.choton26@gmail.com)

Md. Faisal Hanif, Department of Textile Engineering, Port City International University, Bangladesh.

(e-mail: mdfaisalhanif1991@gmail.com)

Mehedi Hasan Chaion, Department of Textile Engineering, Jashore University of Science and Technology, Bangladesh.

(corresponding e-mail: 172207.te @student.just.edu.bd)

Mahbubur Rahman, Department of Textile Engineering, Mawlana Bhashani Science and Technology University, Bangladesh.

(e-mail: mahbub.mbstu@gmail.com)

Sumaiya Siddika, Department of Economics, Mawlana Bhashani Science and Technology University, Bangladesh.

(e-mail: sumaiyamunni34@gmail.com)

Md. Jamir Uddin, Department of Business Administration, University of Newcastle, Australia.

(e-mail: mdjamirjoy92@gmail.com)

Tarikul Islam, Department of Textile Engineering, Jashore University of Science and Technology, Bangladesh.

(e-mail: tarikul.mbstu@gmail.com) techniques to survive the market places [4].

So far, fit is a necessary attribute for selecting apparel. The term 'fit' alludes to the ability to provide enough room to move the human body without difficulty. Likewise, how easily the retailers have engaged with the customers emotionally, psychologically, and behaviorally [5]. Retailers accept that consumers appreciate the store layout and merchandise presentation [6], [7]. As well as, researchers have already demonstrated that visual marketing affects the consumer's mind and influences the other senses, including scent, hearing, sight, touches that push the customers in impulse buying behavior [8], [9].

In the nineteenth century, American museums and department stores displayed their products. Today, displays of products in museums refer to as exhibitions the product displays in stores is visual merchandising [10]. The concept of visual merchandising refers to the communications to customers through windows display, mannequin, floor merchandising as well as assortment, etc., ultimately leading the buyers to purchase that of the products [11]. In a word, visual merchandising is both the presentation of a store and the promotion of the store goods for the ultimate purpose of increasing sales by the teamwork of the store's advertising, display, special events, fashion coordination, and merchandising departments [12], [13]. Store exterior and interior are the two terms in visual merchandising. The attractiveness of the store exterior e.g. window display, façade, and retail premises instigate customers to choose that store where good store interior e.g. orienting factors, layout, signage, featuring motivates customers for purchasing new cloth by eliminating psychological stress [14].

In a study, it is shown that visual marketing encourages the customer to spend more time in a store. It is also reported that two dimensions of visual merchandising e.g. floor merchandising and shop brand name are related to consumer impulse buying in a positive manner [15]. Thus, they endeavor to keep more focus in case of visual merchandising [16]. Therefore, it is clear retailers have to realize their customers and have to emphasize visual merchandising with perfect harmony according to their desires for stimulating the positive moods of the buyers [17], [18]. Zebal and Jackson established the three main cues product authenticity, consumer cosmopolitanism and ethnocentrism, shaping the Bangladeshi local apparel store [19]. Islam et al. explored the relation of Service quality, customer satisfaction and customer loyalty with apparel fashion retail in Bangladesh [3]. Baten et al. discussed the preference of consumers in terms of Local and Global fashion brands [20]. 
For identifying visual merchandising and its effect on customers, some international brands Aarong, Sholpik, and Yellow are selected in Chittagong. This study investigated the dominant factors of visual merchandising influencing customers' buying behavior and in-store promotion activities.

\section{EXPERIMENTAL}

\section{A. Sources of Visual Merchandising}

- $\quad$ Stores (Aarong outlet, Sholpik, Yellow).

- Questionnaire for Customer.

- Primary data and Secondary data.

\section{B. Steps of Methodology}

- Step-1: Visit and select clothing in retail stores.

- $\quad$ Step-2: Identify and visual merchandising elements or techniques.

- Randomly pick 20 customers at each store.

○ Carryout structured interview with visual merchandising.

- Step-3: Fill the questionnaire with the customer.

- Step-4: Get general information from customers.

- Step-5: Identify visual merchandising techniques used in international popular branded stores.

- Step-6: Identify improvements that need to be done to attract more customers.

\section{Elements of Visual Merchandising}

- Exterior Sign

The Exteriors sign is nothing but a sign of the stores that ensures the details about identity, locations and information about the stores.

- Window display

Windows display indicates a large window in the front façade of the stores manipulating the customers who are not fixing their product and the store [21, 22].

\section{- Lighting}

Lighting plays an important role in the customers buying behavior that may be influenced by the color temperature, intensity, making the environment more emotional and looking at the product more attractive as well.

- Interior Signs

Interior signs deliver more clearly and catchy information as well as it builds awareness among customers about brands for future trade [23].

\section{- Focal Point}

In A focal point, all the essential and attractive items are displayed as the customers can easily find out their favorite items as well as catch an overall information about total items of the store.

\section{- Cleanliness}

Cleanness and well organized decorations are always being appreciated creating a fresh environment for customers.

\section{- Music}

In terms of buying more products, music is also an impact factor, even though people are not conscious of its volume and choice. In general, fast music is liable to buy less product and, down tempo music psychologically stimulates customers to stay more time and to see more items of those stores [24].

\section{- Space and Layout}

Space layout is a design that provides the position of the equipment or materials. A retailer always tries to utilize the full space of the floor. The objective of the space layout is to ensure the use of the most area of the floor and to create a customer-friendly environment to find out the customer's desirable product.

\section{Questionnaire for Customer}

The following data sheet was used to collect the survey data to complete the project work on the basis of seven questionnaires.

TABLE 1: QUESTIONNAIRE FOR CUSTOMER

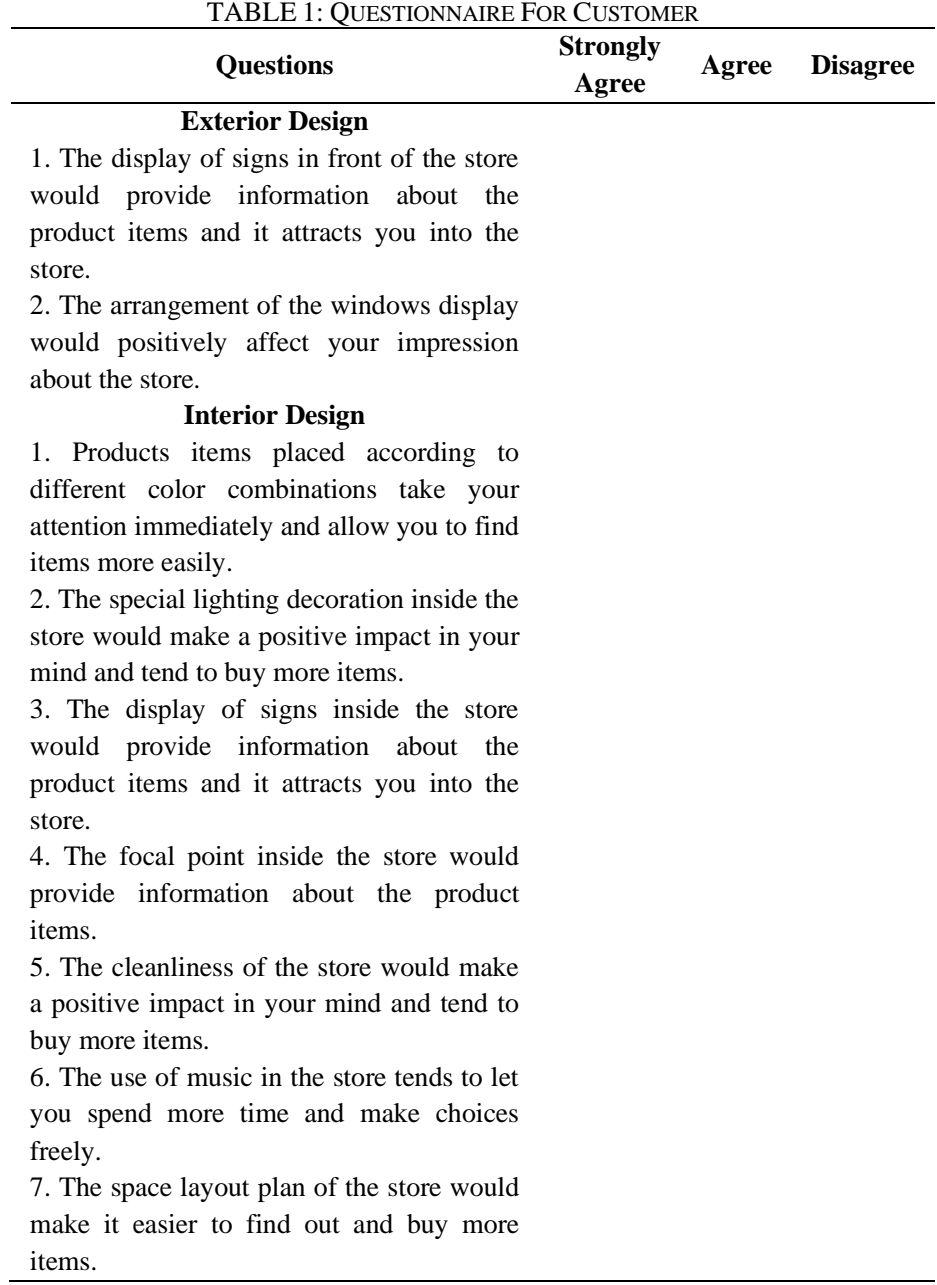

\section{RESUlts AND DisCUSSION}

\section{A. Total Responses}

Responses given to the questionnaire by the customers from all the three outlets is given in the table below:

TABLE 2: Total Responses OF The SAMPle OF 60 Customers From

\begin{tabular}{cccc}
\multicolumn{4}{c}{ ALL THE THREE OUTLETS } \\
\hline Techniques & Strongly Agree & Agree & Disagree \\
\hline Exterior Signs & 35 & 25 & 0 \\
Window display & 15 & 45 & 0 \\
Colors & 25 & 35 & 0 \\
Lighting & 35 & 25 & 0 \\
Interior Signs & 45 & 15 & 0 \\
Focal Point & 25 & 35 & 0 \\
Cleanliness & 55 & 15 & 0 \\
Music & 35 & 25 & 0 \\
Space \& Layout & 45 & 15 & 0 \\
\hline
\end{tabular}




\section{B. Exploration of the Customers' Responses}

i. Study of total reposes

Fig. 1 explored the responses between customers. It is presented that $57 \%$ customers selected strongly agree where $43 \%$ were agreed with those questions.

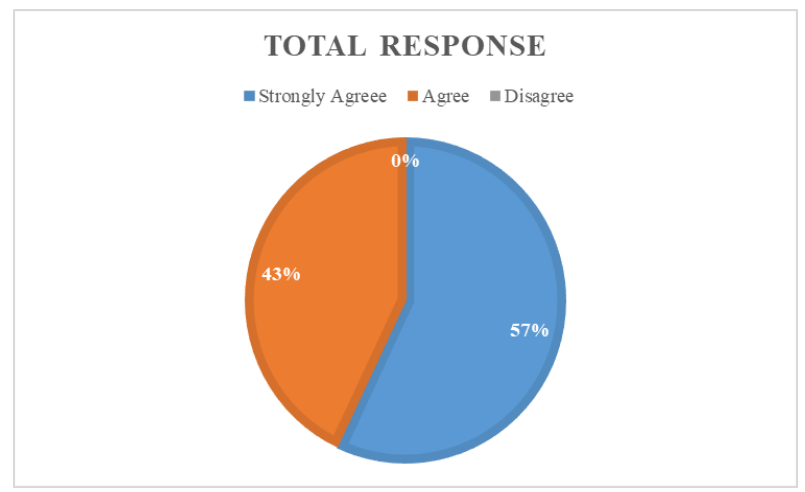

Fig. 1. Study of total responses.

ii. The statistics of responses with respect to gender

According to figure 2, $72 \%$ females and $28 \%$ males responded to this study and filled up the sheet for analyzing data.

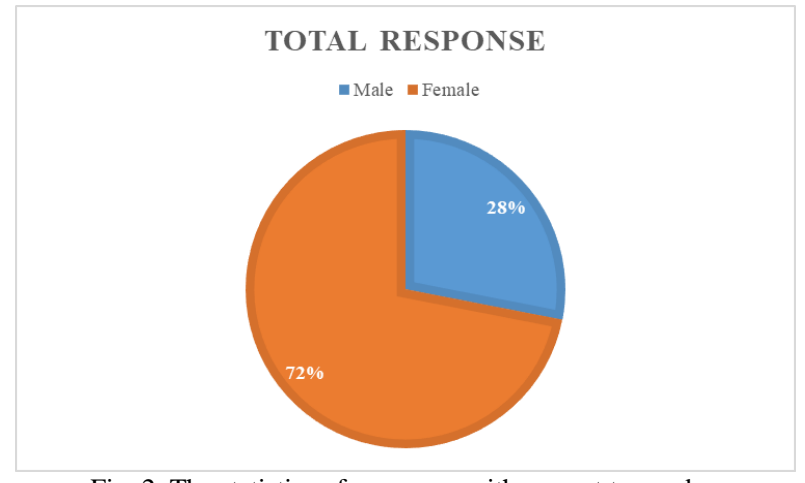

Fig. 2. The statistics of responses with respect to gender.

\section{Analysis of Total Individual Responses}

From Fig. 3, it is observed that interior signs and the space layout are major attention for customers. $16 \%$ of the customers strongly agree with interior signs as well as space layout to find their desired product with no trouble [25]. $12 \%$ of the customers strongly agreed with exterior signs, lighting, and music due to the mental satisfaction of their subconscious mind [26]. Consumers regarded less about windows display but focal point, cleanness, and color on average.

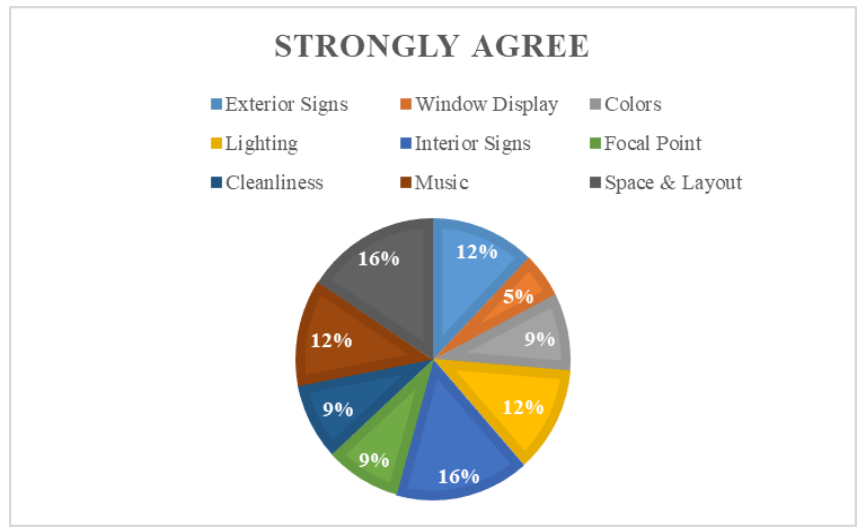

Fig. 3. Analysis of total individual responses.

\section{Discussion}

From this survey, it is found that women exhibited more responses during the survey. In considering the attributes of visual merchandising, every element was suitable for visual merchandising. In that survey, 57\% voted for strongly agreed and others chose the agreed response. In Chittagong, interior signs and space layout are mostly attracting the customers. Interiors sign gives exact information without communicating, whereas a proper space layout gives to find their desired product area without a struggle. Additionally, other attributes add a new degree for impulse buying such as music, focal point, light system, clean environment because impulse buying is interconnected on also mental satisfaction.

\section{CONCLUSION}

Product demand and its sale are dependent on consumer's behavior toward that product. A customer may like that product or dislike that product. At the same time, they are eager to buy it or not. Essentially, consumer's behavior is also stimulated by some vital issues, including product quality, taste, environment, manners of the retailers, and their responsibilities. To continue a profitable business, market strategies have to pattern in such a way that consumers are willing to purchase a new one by ensuring their wants and needs. Along with product quality, visual merchandising is also keeping an important role. Yet, it is also true that all the elements are not the same significance in any problem. By analyzing data of the customers of the three well-known retailer brands Aarong, Yellow, and Sholpik, it evaluated interior signs, and the space layout are vital customers' considerations in the Chittagong region. Overall, the study will help to redesign the retailer shop to fill the desire of the customers and for further studies in Chittagong.

\section{FUNDING}

Authors did not receive any fund or grants to conduct the project work.

\section{ACKNOWLEDGMENT}

Authors would like to thank Aarong, Yellow, and Sholpik retailers brand stores for facilitating the data precisely from their consumers.

\section{REFERENCES}

[1] Bangladesh's economy is soaring - here's why. (n.d.). World Economic Forum. Retrieved October 31, 2020, from https://www.weforum.org/agenda/2019/11/bangladesh-gdp-economyasia/.

[2] Local and foreign fashion brands in a race to grab Bangladesh market. (n.d.). Retrieved October 31, 2020, from https://www.textiletoday.com.bd/local-and-foreign-fashion-brands-ina-race-to-grab-bangladesh-market/.

[3] Islam, M. A., Khadem, M., \& Sayem, A. (2012). Service quality, customer satisfaction and customer loyalty analysis in Bangladesh apparel fashion retail: an empirical study. International Journal of Fashion Design, Technology and Education, 5(3), 213-224. https://doi.org/10.1080/17543266.2012.723754.

[4] Cant, M. C., \& Hefer, M. Y. (2012). Visual Merchandising Displays: Wasted Effort or Strategic Move? The Dilemma Faced by Apparel Retail Stores. Journal of Applied Business Research (JABR), 28(6), 1489-1496. https://doi.org/10.19030/jabr.v28i6.7356. 
[5] Iberahim, H., Zulkurnain, N., Raja, A., Rosli, S., Mara, U., \& Alam, S. (2019). Visual Merchandising and Customers' Impulse Buying Behavior: A Case of a Fashion Specialty Store. International Journal of Service Management and Sustainability, https://doi.org/10.24191/ijsms.v4i1.8141.

[6] Jang, J. Y., Baek, E., \& Choo, H. J. (2018). Managing the visual environment of a fashion store: Effects of visual complexity and order on sensation-seeking consumers. International Journal of Retail \& Distribution Management, 46(2), 210-226. https://doi.org/10.1108/IJRDM-03-2017-0050.

[7] Sharma, M. K., \& Sajid, R. (2016). Retail Attributes Influencing Buyer Behavior in Apparel Stores. World Journal of Research and Review, 2(1), 262987.

[8] Law, D., Wong, C., \& Yip, J. (2012). How does visual merchandising affect consumer affective response? An intimate apparel experience. European Journal of Marketing, 46(1/2), 112-133. https://doi.org/10.1108/03090561211189266.

[9] Kleinová, K., Paluchová, J., Berčík, J., \& Horská, E. (2015). Visua Merchandising and its Marketing Components in the Chosen Restaurants in Slovakia. Procedia Economics and Finance, 34, 3-10. https://doi.org/10.1016/S2212-5671 (15)01594-4.

[10] Art_of_Selling_A_History_of_Visual_Merchandising_sm.pdf. (n.d.). Retrieved

from https://kb.osu.edu/bitstream/handle/1811/44670/Art_of_Selling_A_Hi story_of_Visual_Merchandising_sm.pdf;jsessionid=667173FF266DF 67A7F0803807628159B? sequence $=2$.

[11] Gudonavičienè, R., \& Alijošienè, S. (2015). Visual Merchandising Impact on Impulse Buying Behaviour. Procedia - Social and Behavioral Sciences, 213, 635-640. https://doi.org/10.1016/j.sbspro.2015.11.464.

[12] Seock, Y.-K., \& Lee, Y. E. (2013). Understanding the Importance of Visual Merchandising on Store Image and Shopper Behaviours in Home Furnishings Retail Setting. European Journal of Business and Management, 5(4), 174-187.

[13] Jain, V., Takayanagi, M., \& Malthouse, E. C. (2014). Effects of show windows on female consumers' shopping behaviour. Journal of Consumer Marketing, 31(5), 380-390. https://doi.org/10.1108/JCM04-2014-0946.

[14] Mehta, D. N., \& Chugan, P. K. (2012). Visual Merchandising: Impact on Consumer Behaviour (An Exploratory Study of Apparel Segment in Ahmedabad) (SSRN Scholarly Paper No. ID 2128294). Rochester, NY: Social Science Research Network. Retrieved from https://papers.ssrn.com/abstract=2128294

[15] Widyastuti, P. (2018). Does visual merchandising, store atmosphere and private label product influence impulse buying? Evidence in Jakarta. Journal of Business and Retail Management Research, Volume 12(Issue 3). Retrieved from http://jbrmr.com/details\&cid=365.

[16] Mihić, M., Anić, I.-D., \& Kursan Milaković, I. (2018). Time Spent Shopping and Consumer Clothing Purchasing Behaviour. Ekonomski pregled, 69(2), 89-105.

[17] Kerfoot, S., Davies, B., \& Ward, P. (2003). Visual merchandising and the creation of discernible retail brands. International Journal of Retail \& Distribution Management, 31(3), 143-152. https://doi.org/10.1108/09590550310465521.

[18] Khakimdjanova, L., \& Park, J. (2005). Online visual merchandising practice of apparel e-merchants. Journal of Retailing and Consumer Services, 12(5), 307-318. https://doi.org/10.1016/j.jretconser.2004.10.005.

[19] Zebal, M. A., \& Jackson, F. H. (2019). Cues for shaping purchase of local retail apparel clothing brands in an emerging economy. International Journal of Retail \& Distribution Management, 47(10), 1013-1028. https://doi.org/10.1108/IJRDM-11-2018-0241.

[20] Baten, A., Ishtiaque, A., \& Sarwar, A. (2018). Emergence of International and Local Clothing Brands in Bangladesh and Its Impact on Consumers. Asian Business Review, 8(1), 25-34.

[21] Display window. (2020, June 4). In Wikipedia. Retrieved from https://en.wikipedia.org/w/index.php?title=Display_window\&oldid=9 60734922.

[22] Jain, V., Sharma, A., \& Narwal, P. (2012). Impact of Visual Merchandising on Consumer Behaviour towards Women's Apparel. International Journal of Research in Marketing, 2.

[23] Importance of Retail Store Signage (Interior \& Exterior) | Houston Sign. (2019, July 18). Houston Sign Company. Retrieved from https://houstonsign.com/importance-of-retail-store-signage-interiorexterior/.

[24] Devaney, E. (2018, December 12). Stores Are Using Music to Make You Spend More. Medium. Retrieved November 19, 2020, from https://thinkgrowth.org/stores-are-using-music-to-make-you-spendmore-d6c85974b20b
[25] Ebster, C., \& Garaus, M. (2015). Store Design and Visual Merchandising: Creating Store Space that Encourages Buying Business Expert Press.

[26] Bhalla, S., \& S, A. (2010). Visual Merchandising. Tata McGraw-Hill Education. 